\title{
Shaw in Mid-Twentieth-Century Iran
}

The popular Iranian TV series, Shahrzad (2015-2018) titled after its female protagonist, features a reoccurring image of Shaw. The walls of the bedroom and study of Shahrzad's main love interest, Farhad, include only two portraits — one of George Bernard Shaw and the other of Shakespeare. Shahrzad is set in 1950s Iran and begins in the aftermath of the US led 1953 coup which resulted in the overthrow of the then democratically elected Prime Minister, Mohammed Mossadegh, a figure who had made enemies at home and abroad for seeking to nationalise Iran's oil industry. Farhad is a firm supporter of Mossadegh and a revolutionary, exemplified in his involvement in an unsuccessful plot to free Mossadegh from prison. Farhad's study is integral to the development of his character and the show's plot. Farhad is a man of letters, a journalist, and enthusiast of modernist Persian poetry who reads avidly and often engages in intellectual debate. The study is also where he plots the acts of rebellion that then emerge as he meets with associates and friends, hiding plans and even ammunition amongst his books and other belongings. Shaw's image in this room may at first glance seem insignificant or accidental. When positioned in the larger context of mid-twentieth-century Iranian politics, however, it is indicative of Shaw's strong presence in the emerging debates around social and political reform amongst many Iranian intellectuals and literary figures of the period.

This relationship between Shaw and Iran is not unilateral. Shaw was certainly aware of Iran or 'Persia'. In 1907, Shaw alongside John Galsworthy and Robert B. Cunningham Graham signed a letter to The Times criticising Britain's involvement in the Anglo-Russian agreement. ${ }^{1}$ As Shaw explained later in Common Sense about the War, his disinclination for this agreement was twofold. Firstly, Shaw disliked the 
association with Russia whose government he considered oppressive, describing it as the 'open enemy of every liberty we boast of'. Instead, Shaw considered Germany whose isolation the agreement was designed to cause as in fact a closer ally as for Shaw, sacrificing 'occidental Germany' was like 'sharpening a knife to our own occidental throat'. ${ }^{2}$ Shaw's dislike for the agreement based on Britain's national interests and his division of the world into the 'occident' and the 'other' seems to suggest familiar colonial tropes. ${ }^{3}$ However, Shaw also criticised the agreement for its impact on Iran to acknowledge that this union was an exploitation of this country and its people. Although in the convention it was stipulated that 'contracting parties "mutually engaged to respect the integrity and independence of Persia", the agreement divided Iran into Russian and British domains in which 'Britain and Russia were free to acquire concessions within their spheres of influence without opposition from the other contracting party' as they proceeded to divide 'revenues from Persian customs, fisheries, posts, and telegraphs' to pay off debts that Qajar rulers had accumulated over the preceding decades. ${ }^{4}$ Shaw's socialist critique of the agreement sought to debunk myths propagated by politicians to present the agreement as in the national interests of Britain and Iran. Shaw argued what many Iranians suspected and expressed anger for, that the Anglo-Russian agreement was the 'memorandum of a commercial agreement settling what parts of Persia are to be exploited by the Russian and English capitalists respectively'. ${ }^{5}$

Shaw's intervention in debates around the Anglo-Russian agreement is emblematic of the Shaw that many Iranian intellectuals of the mid-twentieth century knew and admired. For the figures mentioned in this essay, Shaw was an iconoclast, a critic of Western capitalism, and by extension, for some, imperialism. The interest in Shaw is part of a wider engagement with Western European thinking on the Left as 
Iranian intellectuals and artists produced work informed by the thinking of Iran's first communist party, Hezb-e Tudeh (The Party of the Masses) formed in 1941. This article explores the reception of Shaw's oeuvre in Iran in the mid-twentieth century to analyse the ways in which Iranian readers and audiences have read, understood, and used Shaw's work to comment on Iranian socio-political issues. I use translations, criticisms, and productions of Shaw's work in addition to original analyses of Shaw's plays in dialogue with Iranian literature and politics to analyse Shaw's presence in debates surrounding issues of gender, national identity, and political freedom. The following sections explore the reception of three of Shaw's plays with all of which key Iranian intellectuals of the period are connected: Arms and the Man, Saint Joan, and Don Juan in Hell from Man and Superman. This analysis will demonstrate that during this period, Shaw appeared as a recurring point of reference for intellectuals and literary figures with leftist sympathies in Iran in their struggles for a range of reform agendas.

\section{Arms and the Man}

In 1950, the Iranian press widely reported on Shaw's death, with notices and obituaries appearing in publications with a range of political leanings and affiliations. One of Iran's then most popular and currently the country's longest running daily newspaper, Ettela'at (Information), included the news in its front page in a piece titled 'The Greatest Contemporary British Author dies at 94'. Ettela'at was at this point a politically conservative newspaper that was well known for its 'vigorous defence of the Pahlavi regime' ${ }^{6}$ The report included in Ettela'at presents specific details of Shaw's death and general comments on the playwright's popularity: 'At the time of his death, he had found an international and eternal reputation. Until now, at least four of his plays have been shown in cinemas and his literary and comic themes 
are well known across Britain, Europe, America, and other locations.' The writer briefly alludes to Shaw's political views, claiming that Shaw's socialism was in ways 'more severe than worker's socialism' ${ }^{7}$ before divulging more personal aspects of Shaw's life — Shaw's teetotalism and vegetarianism — as was then characteristic of the work of Ettelaat. ${ }^{8}$ Be Suy-e Ayande (Towards the Future), the official newspaper of the Tudeh Party, also reported on Shaw's death. The editors of this publication, however, selected a piece from Reuters that emphasised Shaw's image as a radical thinker in stronger terms than those included in Etela'at: 'His works have rendered void dominant nineteenth-century ideas. Bernard Shaw's intellectually stimulating drama in which political and social issues are discussed have an international reputation'. ${ }^{9}$

Shaw's death coincided with a brief period in modern Iranian history in which the political and public space was opened to include and reflect a multitude of voices. The Anglo-Soviet invasion of Iran in 1941 resulted in the abdication of Reza Shah, who was then replaced with his son Mohammed Reza Pahlavi. As Abbas Amanat notes, the period immediately following this abdication and thus the early years of Mahammed Reza Shah's reign were characterised on the one hand with the occupation's 'disruption of the economy, political instability, tribal rebellions, secessionist movements, frequent imposition of martial law, and growing hatred of foreign powers' and the other 'a national movement for nationalizing Iran's oil industry, the opening of the political space, greater freedom of the press, parliamentary politics, and a nascent labour movement'. The new ideologies that emerged reflected a wide spectrum of opinions and influences 'ranging from MarxistLeninist to ultranationalist and Islamic extremist. ${ }^{10}$ The intelligentsia participated in such political debates often influenced by the ideology of the Tudeh Party. This 
generation of thinkers pursued reforms that did not mean 'necessarily public ownership of the means of production, but instead energetic state planning for rapid industrialization and extensive social reforms, especially redistribution of land, extension of public education, and elimination of the landed upper class'. This was accompanied with a nationalism that considered political and economic independence as intertwined. ${ }^{11}$ Despite this rejection of foreign intervention, the Iranian intelligentsia also looked to many Western thinkers, including Shaw, for inspiration.

Shaw's presence in such debates is evident when exploring the publications to which the Iranian intelligentsia in this period contributed. Sukhan (The Word) was 'a high-quality journal started in 1943 as the organ of the Society of Degree Holders from Teachers' College and published after 1946 as an independent monthly specializing in literary, educational, and social issues, and catering to intellectuals, professors, teachers, school administrators and university staff' ${ }^{12}$ Its contributors include an impressive list of key thinkers and literary figures of the period, including the likes of Bozorg Alavi, Jalal Al-e Ahamad, and Sadegh Hedayat. Amongst the work of a wide range of European thinkers and writers, one can find book reviews and snippets of Shaw's writing included in Sukhan. ${ }^{13}$ It is clear that this work is featured with specific political intentions as contributors and editors of the monthly consistently connect Shaw's writing to Iranian socio-political issues. For instance, in a review of Everybody's Political What's What published in January 1945, the reviewer only identified with their initials, begins the review by explaining Shaw's outlook on democracy: 'In Shaw's view, it is necessary that people have the right to select their leaders, and to give the selected time to prove their competency, and if needed to retract and renew their votes. For Shaw, if the selection of leaders by the people is not done with knowledge and according to the necessary principles, then ignorance and 
political idolatry will always result in the rise of dictators, and even seditious liars and madmen'. They end the review by admitting that Shaw's criticism is 'wholly directed at British institutions' but that the 'philosophical aspects of his views and their comic spirit make the entirety of this book useful and interesting for enthusiastic readers whilst shedding light on many of today's complicated issues' ${ }^{14}$ One such issue for Iranian intellectuals was models of political organisation. In a time in which the Iranian intelligentsia searched for appropriate substitutes for the monarchy whilst being acutely aware of the low levels of literacy in the country — often complaining about public ignorance on a range of issues — Shaw's criticism of Western democracy would have appealed to many of these figures.

Iran's intelligentsia did not only use magazines and periodicals to engage with political issues in this period as they also utilized theater as a medium for criticising existing conditions and pushing for reforms. During Reza Shah's reign, theater in Iran was heavily censored; playwrights and practitioners were required to seek approval from a number of different channels before staging a play. As a result, the theater of this period mainly reflected 'moral and familial themes' such as 'the need to avoid malevolent friends' and 'the perils of consuming alcohol', issues that can be considered as the least dangerous of social topics for an authoritarian regime'. ${ }^{15}$ Following the abdication of Reza Shah, a new branch of theater emerged, one that directly engaged with social and political themes. Similarly to the independent theater movement in Europe, a number of figures in Iran also pursued reforms in writing, production and acting. The most prominent of these figures, often referred to as the father of modern theater in Iran and a leading member of the Tudeh Party, was Abdol Hossein Noushin. Equipped with his experiences in France where he studied acting, Noushin hoped that staging European examples, mostly realist theatre, would result in 
the emergence of plays written by Iranian playwrights that engaged with contemporary socio-political issues in Iran. To that end, he and other members of the Tudeh established Ferdowsi Theater in 1947. Ferdowsi's productions that included Ben Jonson's Volpone and William Shakespeare's The Merchant of Venice were often read as comments on Iranian society. For instance, a critic reviewing the theater's opening production, a translation of J. B. Priestley's An Inspector Calls by the founder of Tudeh, Bozorg Alavi, argued that the play 'mirrored the world of the aristocracy and the pressure that this conceited group exerted on Iranian society'. ${ }^{16}$

In addition to his work on Priestley, Alavi was also the first to introduce Shaw to Iranian readers when he published his translation of Mrs Warren's Profession in 1928. Alavi, like many other individuals associated with the Tudeh Party, was a Shaw enthusiast, claiming that he read most of Shaw's works. ${ }^{17}$ He recollects a time in which he became a vegetarian under the influence of the well-known modernist, Hedayat. Alavi later concluded that vegetarianism was not suited to him and it was during this time that he read an article by Shaw on the topic, prompting him to write to the playwright to ask: 'As someone who is against the killing of animals, do you not use leather? Do you not have a belt?'. Alavi claims that he received a response from Shaw's secretary explaining that vegetarianism is not connected to belts and other leather objects. This letter remained amongst Alavi's papers until the Political Bureau of the Police confiscated it as part of a raid on Alavi's home in April 1937. Alavi claims that he was later tortured for some time to explain the meaning behind this 'letter of espionage', perhaps reflecting Reza Shah's fears of foreign intervention and invasion. ${ }^{18}$

Although Shaw's drama did not feature in the brief history of Ferdowsi, his work appeared in other theaters in this period with comparable results to the aims 
pursued by Noushin and his group. ${ }^{19}$ In 1947, Shaw's Arms and the Man was staged at the Green Room Hall in Tehran in a production directed by Laurence Paul ElwellSutton. Sutton who was then the press attaché at the British Mission in Tehran, had arrived in Iran as an employee of the Anglo-Persian Oil Company. He would later write a number of books on Iranian history, literature, and language, the most famous of which is Persian Oil: A Study in Power Politics - a work that caused controversy in Britain for its criticism of the use of Iran's oil by the British. ${ }^{20}$ Other notable figures involved in this production include Sadegh Chubak, an author of short fiction, drama, and novels who appeared in the role of Bluntschli. Simin Daneshvar, Iran's first female novelist produced the translation used in the production, and this work was later published with an introduction by her husband, another writer and key thinker of the mid-twentieth century, Jalal Al-e Ahmad. I argue that Arms and the Man, when read alongside the specificities of the Iranian context of this particular production and the work of some of the figures involved, seems to present a microcosm of the Iranian society of this period as viewed through the eyes of the members of intelligentsia.

In a review of the production published in Jahan-e No (New World), a magazine targeting in the words of the editor 'those seeking to proceed in line with today's knowledge and science', the reviewer praises Shaw's use of comedy. ${ }^{21}$ In the opinion of this writer, Shaw's style helps to make his criticism palatable and satisfy the human need for spectacle, as Shaw 'fully understands how to entertain and fool his audience in order to sweeten the bitter truths of life presented'. The reviewer considers both the characters in Shaw's play and humanity in general as superficial beings who are 'slaves to colourful games': 'With their limited and skewed viewpoints and 
assumptions, they follow the anomalous institutions and regulations of today's society; they trick and entertain themselves'. ${ }^{22}$

For some Iranian intellectuals of the period, this was not only a suitable evaluation of many characters in Arms and the Man but also a fitting description of Iranian society and politics. Following Reza Shah's abdication and the invasion of Iran by British and Soviet forces, 'different conceptions of nationalism were debated among groups in Iran'.${ }^{23}$ Detailed discussions of these competing models are out of scope of this study; however, it is relevant to note that some of these groups expressed anti-imperial sentiments and severely opposed foreign interference in Iran's affairs. The descriptions of Iran's political discourses produced by some of these individuals seem to follow the emphasis on spectacle and trickery evident in this review of Shaw's play. In an article published in Jahan-e No just five months after this production of Arms and the Man, the writer describes Iran's politics and economics as a 'playing field' in which one team in the north and the other in the south are competing. In the midst of this competition, Iran's politicians are sometimes viewed as incompetent and self-interested puppets much like Petkoff and Sergius who show little military prowess in Shaw's play. In an editorial in Jahan-e No, published in 1948, the writer referring to the selling of arms to Iran by the USA explains:

Iran $[\ldots]$ is caught in an international political storm at the hands of a selfish and adventurous group. Now that we need to open our eyes [...] the USA, in an empty dream, is sending millions worth of arms to Iran. We imagine that if [...] a war breaks out in which the Soviet Union is the attacker, they will take back the arms unwrapped. We think that it is now the turn of the Americans to make slaves of us by giving arms to 
governments that do not represent their people. Iran will not be able to use these weapons, as it needs to wait for the approval of greater powers even when defending its rights against neighbours. This nation will not participate in any international initiative on the behalf of a government that protects the spirit of the directors of this current puppet show.

As the world moved into the Cold War era, many Iranians who were by then frustrated by the use of Iran's land and resources by the competing forces involved in both world wars, were in no way enthusiastic about the possibility of Iran participating in another conflict. Unlike Raina, who greets the news of a battle at Slivnitza in excitement with 'her eyes dilating' (20), these Iranians were under no illusions about the difficulties of conflict. ${ }^{24}$ Interestingly, this editorial was followed by a quote from Shaw to further emphasise these concerns:

Leaders of dictatorships are always less fortunate than officials in a democracy. As soon as a dictator suffers loss in a political battle or defeat in war, this loss and defeat will cost him his life. However, when in a democracy like England, the head of a government is defeated in politics or battle, not only does he not suffer any damages but that he is awarded the title of Lord and offered a first row seat in the House of Lords. Thus, I think that those who ignite the flames of war today are not leaders of a regime but the men of democracy. ${ }^{25}$

In accordance with Shaw's criticism of western democracy and its lack of concern for the consequences of armed conflict, many in Iran also viewed war as purely in the 
interest of bigger players in international politics and to the detriment of nations such as Iran.

This view of war directly opposed — and was thus in some ways a reaction to — Reza Shah's emphasis on military grandeur. A military coup in 1921 officially triggered the events that immediately led to the establishment of the Pahlavi Dynasty to replace the Qajars. Reza Shah, who was then the brigadier general in Iran's Cossack Division backed the coup, signing the announcement of martial law that followed as “Reza, Chief of His Majesty's Cossack Divison and Military Commander of Tehran'. ${ }^{26}$ The military was at the centre of Reza Shah's reign: he divided significant posts in the country among his colleagues in the military ${ }^{27}$ and established a modern centralised army 'upon which his political career depended' ${ }^{28}$ The theater of this period was also used to 'laud the role of Reza Khan Pahlavi and the young national Iranian army'. One particular example of this theater has striking similarities with Arms and the Man. The establishment of central government rule over the Khuzestan province in 1924 resulted in celebrations in Tehran. These festivities included a party for dignitaries in which 'a play was performed about a girl who was so enamoured with the deeds and progress of the Iranian army that, because she could not marry the army, she forced her fiancée to enlist', ${ }^{29}$ just as Raina encourages Sergius to perform her 'heroic ideals' (21). The Iranian audience of the production in 1947 watched Shaw's satirical representation of such attitudes following the embarrassing defeat of Reza Shah's supposedly mighty army by allied forces, and could thus recognise Shaw's exposure of these sentiments as idealistic and lacking substance.

Arms and the Man had further resonances for a mid-twentieth-century Iranian audience that extended beyond Shaw's criticism of romantic ideals. Stoyan 
Tchaprazov interprets the 'eclectic nature of the pieces of furniture' in the opening scene of the play — "occidental" and "oriental," "cheap and rich," "gorgeous" and “paltry” — as a 'sign of Raina's failed attempt to mimic Western models'. Tchaprazov uses this as evidence to argue that Shaw's Bulgarian setting of Arms and the Man 'exposes the play's participation in particular discursive trends and norms of its time, namely, fin-de-siècle Balkanism: the construction of Balkan identity as the "other within Europe"—not the "savage" Indian or African "other," but an improperly civilized "other".${ }^{30}$ I argue that for an Iranian audience, this mixture of the 'oriental' and 'occidental' and Raina's failure to perform a Western European identity operated in contrasting ways to Tchaprazov's interpretation. In his introduction to Daneshvar's translation of Arms and the Man, Al-e Ahmad is laudatory in his evaluation of Shaw's writing as he connects the play to Iranian concerns: 'This play directly presents the definition of concepts such as 'self sacrifice', 'patriotism', and 'responsibility', which have taken on particularly vulgar forms in our culture, as attempts to escape, the pursuit of trophies, and the flogging of dead horses'. ${ }^{31}$ Al-e Ahmad's interest in Shaw may at first seem unlikely. After all, Al-e Ahmad wrote Gharbzadegi (1962), translated as 'Occidentosis' or 'Westoxification', a work that anticipated 'with remarkable precision points made by Edward Said in his Orientalism.${ }^{32}$ In this text, Al-e Ahmad describes the disappearance of national character and opposes the spread of western values, economics, and culture in Iranian society:

If we define Occidentosis as the aggregate of events in the life, culture, civilization, and mood of thought of a people having no supporting tradition, no historical continuity, no gradient of transformation, but having only what the machine brings them, it is clear that we are such a 
people. [...] Occidentosis thus characterises an era in which we have not yet grown familiar with the preliminaries to the machine, the new sciences and technologies. Occidentosis characterizes an era in which the logic of the marketplace and the movement of oil compel us to buy and consume the machine. ${ }^{33}$

As critics have argued, despite Al-e Ahmad's criticism of the 'intrusion of western hegemonic cultural and economic apparatuses and an infiltration of westoxifying illness', European and American thinkers and writers influenced Al-e Ahmad. ${ }^{34}$ In the words of Mehrzad Boroujerdi, Al-e Ahmad 'belonged to a generation that was at once inspired by the West, but politically opposed to it' ${ }^{35}$

Many of Shaw's characters in Arms and the Man seem to follow Al-e Ahmad's description of the occidentotic or in Tchaprazov's words 'wannabe Europeans'. ${ }^{36} \mathrm{Al}$-e Ahmad describes the occidentotic as a person with 'no character': 'He is a thing without authenticity. His person, his home, and his words convey nothing in particular, and everything in general. It is not that he is cosmopolitan, that the world is his home. He is at home nowhere but everywhere'. ${ }^{37}$ The combination of the 'occidental' and 'oriental' on stage in Arms and the Man transforms Shaw's characters into the occidentotics that Al-e Ahmad describes; people who have abandoned their roots and whose performance of Western European identity clearly lacks authenticity. Occidentotics are - like Raina who is quick to remind Bluntschli that their home is the 'only private house that has two rows of windows'(35) ostentatious individuals and the 'most faithful consumer(s) of West's industrial goods' whose homes look 'different everyday'. ${ }^{38}$ They are without conviction and belief, pursuing 'no direction' or 'aim'; like Sergius who aimlessly moves from one 
woman to the other whilst declaring his love to both. ${ }^{39}$ An occidentotic only fears one thing, that others discover their 'brain is empty'. ${ }^{40}$ Perhaps Raina and her family fear the same as they repeatedly make references to their library; one that Shaw reminds us is 'not much of a library', consisting 'a single fixed shelf stocked with old paper covered novels' and predominantly used to exhibit 'trophies of the war and chase' (61). Nicola later confirms this primary function of the library as a marker of social status when he reproaches Louka for her tendency 'to look at the books', in his words a 'habit above her station' (72).

According to Al-e Ahmad, Iranians are 'stuck with occidentotic leaders'. Such individuals are often found in positions of power and authority: 'the lumpens from every trade and class customarily come to power — that is, the misfits, the idle, those with no will of their own' ${ }^{41}$ Raina and her family for some members of the Iranian intelligentsia exemplified the ruling classes, who they viewed as incompetent puppets of Western powers, imitating with little success Western values and culture. This was confirmed by the directorial decisions made in this production: the few images that remain of the performance show Bluntschli and Sergius in European military attire as was also worn by Reza Shah and his national army. ${ }^{42}$ The decision to maintain the play's original setting could in some ways have emphasised the Iranian connections thus far discussed. In this context, these images of Iranian performers wearing western clothes on stage is reminiscent of Reza Shah's dress reforms through which Iranians were encouraged to replace traditional dress with European garments. ${ }^{43}$ The foolishness of Shaw's characters on stage mocked Reza Shah's campaign to modernize Iran partly through superficial changes in appearance.

In this context and in contrast to Tchaprazov's description of Bluntschli as the superior western European, Bluntschli represented the intelligentsia who opposed 
these values and practices. ${ }^{44}$ The Iranian production in 1947 blurred boundaries between performer and character; Chubak who had by then produced a collection of short stories focusing on the more morbid aspects of life in Iran titled Kheyme Shab Bazi (The Puppet Show) (1945), appeared as Bluntschli. This connection between the two was noted in the review published in Jahan-e No. The reviewer praised Chubak's acting before concluding that: 'this mastery is influenced by the correspondence between the personal characteristics and views of Sadegh Chubak and the views and opinions of Bluntschli' ${ }^{45}$ Interestingly, Chubak published a one Act play two years later, Toop-e Pelastiki (Plastic Ball) in which he criticised the authoritarianism of Reza Shah's reign and also, like Shaw, mocked the ruling military figures. The play's protagonist, Iran's Interior Minister, Mirza Khan Dalaki, is left frightened at the presence of a soldier outside his home, assuming that he is to be arrested. He considers possible reasons for his arrest, asking for help from his friends and family, including an opium smoking general, none of whom are prepared to risk their lives and livelihoods. The play ends by revealing that the commotion and fear caused was unnecessary as the soldier was only there to retrieve a plastic ball that his son had accidentally thrown into Mirza Khan's yard.

\section{Saint Joan}

The 1953 coup marked the 'gradual return to autocratic practices' in Iran, ushering in a 'politically repressive' era in the county. ${ }^{46}$ In theater, those associated with Noushin, who alongside other members of the Tudeh Party was arrested in 1949, were forced to publicly denounce their affiliations with the theater maker and pledge their allegiance to the Shah. In this context, Shahin Sarkisian was one of the few figures that continued Noushin's work in modernising Iranian theater. He gathered a group of students, graduates of Acting Schools, and other theater enthusiasts in his flat to read 
plays by Anton Chekhov, Eugene O'Neil, and Shaw, and to discuss Stanislavski's System. ${ }^{47}$ Like Noushin, Sarkisian also used European realist drama as a model to inspire Iranian writers to compose works engaging with national socio-political issues. He translated and wrote on a range of European and North-American playwrights but nowhere in his writing was he more complimentary than when discussing Shaw. In an article titled 'Our Aims', Sarkisian described his ambitions in theater, identifying realist drama as 'the real and true' theater of the world. $\mathrm{He}$ claimed that establishing such a theater in Iran required staging the work of the 'great writers of the world': 'Ibsen, Strindberg, Chekhov, Pirandello, O’Neil are of those writers whose work can be a close and valuable facilitator for improving a modern theater. And this is true of the writings of George Bernard Shaw due to the observant and realistic outlook of this social writer'. In a chapter on Shaw, Sarkisian reiterated this image of the playwright as a prophet and visionary, again emphasising the connections between the plays and contemporary socio-political issues: 'Today, he [Shaw] is a writer who tries to better humanity in order to replace irrationality with rationality, chaos with order, and injustice with justice'. ${ }^{48}$

Unsurprisingly, one of Sarkisian's earliest productions was of Shaw's Mrs Warren's Profession. Sarkisian and his group began rehearsing the play in 1960, most probably working with Alavi's translation. Much to the disappointment of Sarkisian and those working with him, however, their production never materialised. As with Shaw's struggles in staging his work in the West End, the reasons were mainly financial. This was in stark contrast to the promising initial stages of the project: Dr Mehdi Forough, the head of the newly found Department of Dramatic Arts — an institution developed two years earlier to organise theatrical endeavours in Iran donated a substantial amount of money (five thousand toomans) to fund the preparing 
of sets and costumes. Mostafa Oskooie, a well-known actor and director, also lent his assistance, allowing Sarkisian to use his now famous Anahita Theater for the production. Like the performers participating in the Vedrenne-Barker seasons and the private dramatic societies of the late nineteenth and early twentieth centuries in England, Sarkisian was also working with a group of performers whose motivations for participating were not financial. This group comprised an impressive list of performers who worked on the production for free for more than a year. The premiere was finally in sight with a full dress and tech rehearsal underway when the playhouse experienced a power cut. This was not merely a technical issue: Oskooie had not paid the electricity bill before traveling to the south of Iran for another production, assuming that Forough would pay instead. According to a member of Sarkisian's group, Arbi Avansian, a director and scenic artist, Sarkisian who was illiterate in business matters failed to secure further financial assistance or an alternative venue for the performance. Consequently, the production was cancelled with Sarkisian suffering great financial loss as he was made to reimburse the Department in instalments deducted from his monthly wages. ${ }^{49}$

Despite these events, this production began the theatrical activities of one of Iran's most famous modernists, Forough Farrokhzad as she rehearsed the role of Vivie in the production. She would later work with Sarkisian again on a successful staging of Pirandello's Six Characters in Search of an Author and another disappointingly incomplete Shavian project. Before her untimely death at the age of thirty-two in 1967, Farrokhzad was translating Saint Joan and planning a staging of the play with Sarkisian in which she appeared as its famous female protagonist. ${ }^{50}$ At first glance, this interest in Shaw seems unlikely. It connects Farrokhzad, a poet often criticised for the eroticism of her poetry and well known for her passionate 
explorations of sexual desire and yearning with Shaw, a playwright with an interest in a cerebral theater. A study of Farrokhzad's poetry and the little that is available of her personal papers, however, reveals many affinities in the poet's life as discussed in her work and Joan's predicament in Shaw's play that may explain her interest in Saint Joan. As Michael C. Hillmann argues, Farrokhzad's poems are deeply autobiographical: 'In Farrokhzad's case, the combination of openness, guilelessness, and minimal self-censorship contributes to making a poem of her life'. ${ }^{51}$ The controversy that has and continues to surround Farrokhzad is perhaps due to this personal quality of her writing. Some early critics of Farrokhzad's poetry fiercely condemned her candid expressions of female sexuality while the Islamic Republic has in periods banned the publication of her poetry for the same reasons. I would argue that Farrokhzad's autobiographical approach extends beyond her poetry to involve all her artistic endeavours including her interest in theater. Hillman, relying on the autobiographical quality of Farrokhzad's art, briefly discusses the similarities between Shaw's Joan and Farrokhzad in his account of the poet's life and work, summing up that like Joan's, 'Farrokhzad's life as well seems in large measure a similar protest in a similar context of Iranian religious and social interference in her attempt to be an individual' ${ }^{52}$ I aim to extend these connections further to consider the ways in which Farrokhzad could have identified similarities in the conflicts of the play and Joan's legacy as depicted in Shaw's Saint Joan with events in her own life.

In the preface to Saint Joan, Shaw consistently draws parallels between the fictional world of the play in fifteenth century France and his contemporary society. He makes such connections to dismantle any suggestions that a repetition of Joan's fate is impossible in the twentieth century: 'We must face the fact that society is founded on intolerance. There are glaring cases of the abuse of intolerance; but they 
are quite as characteristic of our own age as of the middle ages' ${ }^{53}$ Shaw provides the treatment of the suffragette, Sylvia Pankhurst as an example of this intolerance of new ideas and practices (29). These similarities are then further emphasised on stage in Saint Joan; characters speak in modern English and in the epilogue, the present literally meets the past with the entrance of 'a clerical-looking gentleman [...] in the fashion of the year 1920' (160). The drawing of such parallels is integral to Shaw's model of the history play in which he uses historical events to comment on contemporary socio-political issues. Farrokhzad's interest in Saint Joan is thus significant. It reflects Shaw's success in achieving his aim as it demonstrates that Farrokhzad identified affinities between Shaw's depiction of a fifteenth-century French society and the mid-twentieth-century Iranian context in which she lived. Farrokhzad lived in a particularly socially and politically turbulent period in Iranian history. In the 1950s, when Farrokhzad began to seriously write poetry, Iran was 'multicontextual'; 'different social sets saw reality through different lenses that often reflected varied and sometimes contradictory images and made it difficult to reach consensus' ${ }^{54}$ These clashes of ideas that involved differing manifestations of modernity and traditionalism were perhaps most apparent in attitudes towards women's issues. The Constitutional Revolution (1905-11) inspired the first phase of the women's movement in Iran and since then, the place and role of women has been a hotly contested topic in Iranian society and politics. By the mid 1960s, women in Iran gained certain legal and political rights as part of the Shah's 'The White Revolution', which in addition to a number of social, political, and economic reforms also included women's suffrage. ${ }^{55}$ These changes were not welcomed by all, however, as the Shah's policies were met with opposition from clerics and religious conservatives as well as some secular intellectuals. ${ }^{56}$ In the preface to Saint Joan, 
Shaw declares that 'the degree of tolerance attainable at any moment depends on the strain under which society is maintaining its cohesion' (41). In light of this, it is not surprising that in a time in which consensus among Iranians on many issues including the status of women seemed impossible, Farrokhzad, like Joan, met immense intolerance for her 'different set of ethical evaluations', specifically her challenges to some secular and traditional models of womanhood (7). Consequently, as in Shaw's play in which the secular arm and the Church collaborate to destroy Joan, Farrokhzad also faced relentless criticism from many critics, some of whom failed to agree on much other than their dislike of the poet.

Shaw's Joan, like Farrokhzad, rebels against traditional understandings of women's role as nurturers and their place as belonging to the home. Shaw highlights this aspect of Joan's life and character through centring some of the hostile reactions shown to her in the play on her rebellions against gender norms. Joan's critics view her refusal to marry and her decision to become a soldier — a strictly male's profession — as unnatural. In her trial, D'estivet describes Joan's acts of rebellion summed up in her insistence on wearing men's clothes as 'indecent' and 'abominable', concluding that Joan is a sorceress (137). Others similarly resort to name calling in order to explain and dismiss Joan's difference. They use labels often associated with women who transgress societal restrictions, accusing Joan of sexual promiscuity — she is referred to as a 'slut' on more than one occasion — and madness. ${ }^{57}$

These accusations were all too familiar to Farrokhzad. In one of Farrokhzad's early poems, 'Sin', first published in the magazine Rowshanfekr (The Intellectual) and later included in her second collection Divar (The Wall) (1956), the poetic voice confesses: 
I have sinned a rapturous sin

In a warm enflamed embrace,

Sinned in a pair of vindictive arms,

Arms violent and ablaze ${ }^{58}$

The frankness of these early poems that chronicle the sexual encounters of a woman resulted in uproar with many critics condemning the poems on moral grounds. Others interpreted Farrokhzad's expressions of female sexuality as a sign of promiscuity. Farrokhzad was plagued in her life with unwanted sexual advances from members of the Persian literati ${ }^{59}$ — some even publicly claimed that they had relationships with her $^{60}$ - while her poems were published in literary magazines accompanied by sexualised imagery like the silhouette of a naked woman. ${ }^{61}$

Throughout her life, Farrokhzad, in a similar fashion to Shaw's Joan, would attempt to distance herself from such misconceptions to assert her individuality. A key concern for Shaw in Saint Joan is Joan's decision to dress as a soldier, a choice for which Joan is repeatedly criticised and ridiculed by her male critics. It is plausible to think that these characters' fascination with Joan's attire would have had specific cultural resonances for Farrokhzad as she lived in a society obsessed with female bodies and where women's dress was often policed. For instance, in 1936 Reza Shah ordered the mandatory unveiling of women, a decree that resulted in some retreating to their homes to preserve their religious identities while others choosing to unveil faced backlash from members of their communities. ${ }^{62}$ Indeed, Farrokhzad was also the topic of gossip for her at times 'flamboyant' wardrobe choices. ${ }^{63}$ 
Shaw's Joan, whom Shaw describes as 'neutral in the conflict of sex', does not defy gendered expectations to be provocative (8). She dresses in male attire in order to draw attention away from gendered assumptions that follow her biological sex to be viewed as an individual: 'I am a soldier: I do not want to be thought of as a woman. I will not dress as a woman' (138). These lines should not be taken to conclude that Joan desired to instead be male as in the preface Shaw questions the innateness attributed to gender norms and roles: 'But it is not necessary to wear trousers and smoke big cigars to live a man's life any more than it is necessary to wear petticoats to live a woman's'(20). Shaw's Joan desires to extend beyond these assumptions, to exist in a 'third order, neither male or female' in which she is treated as an individual. ${ }^{64}$ In her later years, Farrokhzad viewed her poetry in similar ways. In response to an interviewer who described her work as 'clearly feminine', perhaps frustrated with the constant attention on her gender identity over the merits of her work, Farrokhzad replied: 'What is important is the work produced by a human being and not one labelled as a man or a woman. When a poem reaches a certain level of maturation, it separates itself from its creator and connects to a world where it is valued based on its own merit'. ${ }^{65}$ Farrokhzad's later work presents a shift in focus in which the poet rejected "feminine" and "feminist" writing in favour of a "female" vision, a move towards human rather than strictly female concerns and preoccupations' ${ }^{66}$

As Milani explains, the hostile reactions shown to Farrokhzad were not merely due to the content of her poetry. Like Joan who is shunned for acting as a warrior and entering public life, thus the male domain, Farrokhzad was also outcast for her decision to write, an occupation then strictly reserved for men in Iran. In her study of Iranian female writers, Milani explains: 'The exposure of the body of their writing, 
like exposure of their own bodies, proved to be a costly enterprise. Women paid for their literary unveiling with reputations of immorality, promiscuity, even heresy. Struggling in isolation, they were locked behind bars as lunatics, driven to suicide, forced into exile'. ${ }^{67}$ Indeed, Farrokhzad's life was 'marked by bouts of depression, by nervous breakdowns and by attempted suicide'. ${ }^{68}$

Thus, Shaw's interpretation of Joan's attempt to escape from Beaurevoir Castle by jumping from a tall tower as the choosing of an 'alternative to life without liberty' would have appealed to Farrokhzad. Shaw refuses to accept dismissals of this event in Joan's life as merely a 'suicidal tendency', another sign of Joan's supposed madness (21). When questioned, Joan explains the jump by comparing herself to an imprisoned bird: 'If you leave the door of the cage open the bird will fly out' (132). For Shaw, Joan does not solely choose to partake in a life-threatening activity but is instead driven to such an action. The lack of care shown to the consequences of the jump is a direct result of the restrictions placed on Joan's individuality by the cultural and political institutions of her society. Moreover, as with Forough's refusal to forego writing in the face of immense adversity, ironically Joan's suicide is simultaneously also a reclaiming of agency as she desperately tries to find a means of escape. Farrokhzad viewed her poetry in a similar fashion. In 'Only Voice Remains', a poem included in her posthumously published collection Iman Biavarim be Aghaz-e Fasl-e Sard (Let Us Believe in the Dawn of the Cold Season) (1974), Forough, perhaps in response to her critics begins, 'Why should I stop?'. She later laments:

Voice, voice, voice, only voice remains. 
In a world of runts,

Measurements orbit around zero.

Why must I stop? ${ }^{69}$

As Farrokhzad is determined to continue living life on her terms, she emphasises the significance of 'voice' and by extension her poetry to her existence. The lonelier Farrokhzad felt, the deeper she delved into her poetry as her sole companion.

The avian imagery used in Joan's explanation is also a recurring motif in Farrokhzad's poetry. In a study of the avian imagery used in Saint Joan, Tony J. Stafford identifies a number of occasions in the play in which birds and bird-like qualities and activities are mentioned. Stafford concludes that the significance of this is to claim, 'Joan's orientation is skyward and her guidance is from high, the clerics are of this world and their vision limited to the things of this world' ${ }^{70}$ Similarly, Farrokhzad often compared herself to a bird as a marker of distinction to emphasise at times the limitations placed on her and on other occasions her strengths. In her first collection significantly titled Asir (Captive) (1955), Forough uses avian imagery to, like Joan in the trial scene, emphasise her feelings of entrapment. In the poem 'Captive', which has striking autobiographical elements - Farrokhzad was then married to Parviz Shapour whom she would later divorce leaving behind her son — the poetic voice compares herself to a 'bird captive in a cage' living 'behind raw iron icy bars' as she laments on her lover from whom she is separated by her 'jailor' but more importantly by her love for her child: 'Should I one day break out and flee/What could I say to this crying child?'. ${ }^{71}$ In another poem, 'Inaugurating the Garden' 
published in Farrokhzad's fourth collection, Tavalodi Digar (Reborn) (1964), the poet compares two lovers who 'have seen the garden', a metaphor for understanding the true meaning of love, as white innocent doves who 'look to the ground/from their towering white height'. She contrasts the lovers to those around them, whom the poetic voice considers as 'crows' gossiping and passing judgement as they 'carry the news of us to the city'. ${ }^{72}$

Finally, Shaw's Epilogue in which the playwright engages with Joan's legacy connects in significant ways with Farrokhzad's literary afterlife. In the Epilogue, Shaw combines tragedy with comedy to mock the reverence paid to Joan following her death by the very people and institutions who condemned her - The Gentleman declaring Joan's cannoization fails to attribute a serious tone to the announcement as his introduction is met with 'uncontrollable laughter' from other characters on stage mocking his dress. Farrokhzad observed and criticised a similar hypocrisy and cunning amongst Iran's literati. In an undated letter to her brother Fereydoun, who was at the time planning to return to Iran from Germany, Farrokhzad complained: 'Here you must live amongst those who have destroyed my life. They are nothing, nothing, nothing [...] These who are today publishing a hundred photos of you a day in their magazines and shoving them down people's throats will do nothing tomorrow but speak ill of you wherever they sit, and write ill of you wherever they write'. ${ }^{73}$ It would not have surprised Farrokhzad to learn that following her death, those who had spent many words throwing insults and accusations at her, were now publishing obituaries praising the deceased poet. In the words of Farrokhzad's sister, Pouran, 'in every magazine you'd open, you'd read remembrances right and left and eulogies and sighs and regret. All of this from those very people who during Forough's 
lifetime not only did not play a role in her life, but also harassed her as much as they could and gradually dragged her toward destruction'. ${ }^{74}$

There is another connection between the Epilogue and Farrokhzad's legacy, interestingly one of which Farrokhzad could not have been aware. While Joan's canonisation may suggest acceptance of her by the institutions that initially denounced her such as the Catholic Church, the Epilogue highlights the unease with which Shaw's genius continues to be received to again emphasise similarities in the intolerance shown by the society of the play's setting and the twentieth century. In response to the question, 'Shall I rise from the dead, and come back to you a living woman' (163), Joan is confronted with a barrage of excuses explaining why she should remain dead as the stage is plunged into darkness eventually leaving only Joan visible but isolated, standing — in Farrokhzad's famous words describing herself — 'a lonely woman'. ${ }^{75}$ Farrokhzad has a similarly precarious legacy. On the one hand, she is immensely popular in Iran with a huge 'social presence' in Iranian culture. ${ }^{76}$ On the other hand, however, Farrokhzad suffers an institutional effacing of her legacy. Her work is not included in the curriculum and since the 1979 revolution even the publication of her poetry has been banned in periods. As Fatemeh Keshavarz explains, Farrokhzad is also omitted from 'New Orientalist' accounts of Iranian culture and history as Farrokhzad shatters stereotypes of Middle-Eastern women as passive and submissive. ${ }^{77}$ Although some of the reactions to Farrokhzad since her death seem to suggest that she has undergone a canonization similar to that of Joan of Arc, as with Shaw's Joan, Farrokhzad's iconoclasm continues to make many uncomfortable. If Farrokhzad were alive today, perhaps she would also ask: 'O God that madest this beautiful earth, when will it be ready to receive Thy saints? How long, O Lord, how long?' (164). 


\section{Don Juan in Hell}

Another Iranian intellectual of the mid-twentieth century, who used Shaw's work to comment on Iranian socio-political issues, was writer and director, Ebrahim Golestan. Golestan was well acquainted with some of the figures thus far discussed in this essay. He was in a long-term romantic relationship with Farrkhozad at the time of the poet's death, and he was also a close friend of Daneshvar. This friendship appears to have triggered events that led to the publication of Golestan's translation of Don Juan in Hell. Golestan recollects that he translated Shaw's text some time in $1950-$ joking that this may have caused the playwright's death approximately a week later — with no intention of publishing the translation. After reading this work for Daneshvar and Al-e Ahmad, Daneshvar, who was then lecturing at Tehran University, requested that Golestan reads the translation publicly for some of her students.

Golestan, enlisting the aid of the well-known actor and director with whom he was working on a film at the time, Parviz Sayyad, later directed a production of the play staged at Kuchak Theater in 1974 in which Sayyad appeared as the Devil. ${ }^{78}$ The translation was published the same year.

Golestan's translation includes a number of changes to Shaw's original, mainly to adapt the text to an Iranian context and in Golestan's words to 'update' some of its discussions. ${ }^{79}$ Golestan omits certain cultural references unfamiliar to Iranians: for instance, some of the discussions of Wagner, Nietzsche, and Mozart are excluded from Golestan's translation. Moreover, mentions of events and people in previous sections of the play are discarded to create a coherent and freestanding Act to be performed independently from the remainder of Man and Superman. In the preface, Golestan claims that although Shaw wrote Don Juan seventy-five years earlier, 'it remains fresh for us'. Golestan demonstrated this topicality of the play in 
performance by incorporating references to Iranian politicians and political events. In the production in 1974, as Golestan explains in interviews and the preface to his translation, the Devil was made to resemble Shah's then Prime Minister Amir Abbas Hoveyda to reflect Golestan's 'disgruntlement with the Pahlavi regime and Hoveyda as one of its most visible symbols' ${ }^{80}$

Hoveyda was the Shah's longest serving Prime Minister, holding office for thirteen years between 1964 and 1977. Accounts of Hoveyda's life and character present the Prime Minister as an articulate, charming, and well-travelled individual; a polyglot with a passion for the French new wave writers and philosophers. Hoveyda's interest in philosophy and literature 'gained him access to some of Tehran's most coveted intellectual circles' resulting in a close friendship with Chubak that lasted till the end of Hoveyda's life. ${ }^{81}$ These two seemingly irreconcilable sides to Hoveyda's character, his liberalism and passion for intellectual debate on the one hand with his support for the authoritarian policies of the Shah on the other, caused many to view Hoveyda as a man without principles whose only motivation was the "maintenance of his high office with its perks and privileges'. ${ }^{82}$ Indeed while the 'conservatives never trusted' Hoveyda, many on the Left 'never saw him as anything other than a boulevardier. ${ }^{93}$ It seems that Golestan shared and occasionally expressed this latter perception of the Prime Minister. The two men were acquaintances but their relationship was for the most part filled with hostilities. Milani reports a particularly tense exchange between the two men in which 'jocular verbal banter' soon 'escalated into a serious confrontation' with Golestan taking off his shirt, making it into a ball and throwing it at Hoveyda before yelling: 'smell it, it has the sweet smell of conscience ... not the stench of someone who has sold his soul' ${ }^{84}$ 
There is much in Shaw's portrayal of the Devil that makes this character a suitable vehicle for Golestan in expressing his criticism of Hoveyda. As John A. Bertolini argues, in Don Juan, Shaw 'practices the principle he enunciated in the Epistle Dedicatory, namely, that all his characters are right from their several points of view', resulting in the 'powerful persuasiveness of the Devil's arguments' ${ }^{85}$ The Devil, like Hoveyda, is charming and eloquently spoken, demonstrating extensive knowledge of his opponent's arguments at one point claiming, 'I am also on the intellectual plane' ${ }^{86}$ Golestan considers these charms as mere illusions with no aim other than to deceive. In an obvious attack on Hovyda, Golestan describes the Devil as a 'performer who is pleased with his performance as he knows there is nothing behind them. There is nothing other than a belief in nothing, so he must conceal this in a performance. But, he presents his lack of attachment as freedom. He cannot stand strong men. Little men are enough for him. He despises all shining passion and intellect. He is the master of darkness, an imposter '(9). Thus, Golestan connects the Devil's passion for aestheticism and beauty in Shaw's text to Hoveyda's liberalism and interest in intellectual debate that Golestan considered as hollow and lacking conviction. Such evaluations of Hoveyda were not without foundation as he often drew on 'his cosmopolitan flair, his reputation as a polyglot and a liberal, his quick wit, affable style and his delight in clever repartee with journalists' to defend the Pahlavi regime's violations of human rights. ${ }^{87}$

Golestan makes a number of additions and alterations to Shaw's text, which reflects and highlights his personal and ideological differences with Hoveyda. In accordance with descriptions of the Prime Minister as 'shrewd' and 'well-versed in the art of court flattery', Golestan makes seemingly minor adjustments to produce a Devil that is more overtly manipulative. ${ }^{88}$ He provides different translations for the 
term 'cynical'. When Don Juan uses this word to refer to women's tendency to 'view man as a separate sex' (147), Golestan uses the term 'bad jens' (49), which suggests wickedness. However, later in Don Juan's final exchange with the Devil, in which Don Juan uses 'cynical' (171) to describe his opponent, Golestan combines two words, 'khorde shishe dar' and 'chendesh' (85), neither of which are direct translations of the original to describe the Devil as hated and deceitful. A line from the Devil that Shaw's stage directions indicate should be delivered 'angrily' (171) precedes this. Again, Golestan extends Shaw's descriptions to write: 'discarding his seductive soft tone for bluntness, anger, and splitting candour' (85). Golestan further highlights the Devil's role as a manipulator when in place of the Statue positioning 'himself on the grave trap outside The Devil' (172), he opts for the Devil to prompt the Statue's descent into hell by 'wrapping his cane around him and pulling' (87). This simple use of prop acts as a direct reference to Hoveyda who also used a cane when walking.

Shaw's Don Juan describes Hell and Heaven in the following terms: 'Hell is the home of the unreal and of the seekers for happiness. It is the only refuge from Heaven, which is as I tell you, the home of the masters of reality' (139). Hell is in the Devil's view a place for sympathizers 'with joy, with love, with happiness, with beauty' (134), or in Don Juan's view 'idle humans' (127) with no time for contemplation. In his film Mysteries of the Treasures at Ghost Valley (1974), Golestan mocks this sole pursuit of beauty and happiness in a 'satirical parable' directed once again at the Shah and his Prime Minister. The film is the story of a villager who accidentally discovers a treasure trove. The man spends this newfound wealth in extravagant ways, hosting a party and constructing 'an absurd structure' resembling a 'phallus' in the village. The teacher of the village, bearing similarities 
with Hoveyda, at first tries to curtail the man's plans but soon gives in. The film ends in the aftermath of an explosion, a 'metaphor for revolution', that occurs during the construction of new roads to the village. Milani describes the film as a 'subversively clever account of Iran's skewed path to modernity', referring to the Shah's reforms in the 1960 s and 70s that sought to modernise Iran's culture, economy, and industries. ${ }^{89}$ In this period, Iran expanded its infrastructure and capacity to produce goods. While on the one hand this 'promised a viable mixed economy for a developing nation', the plan in its later years became 'overambitious and out of control, leading to waste, corruption, and nepotism'. Many critics on the Left 'belittled much of Iran's industrialization as a mere "assembly" of useless products that had been imposed by Western consumer culture and were for the benefit of a "dependent bourgeoisie". 90 Presumably, Golestan read the Devil's worship of beauty and happiness in Don Juan in similar ways to connect this with the emphasis on production in Shah's reforms and Hoveyda's complicity in the errors made. Moreover, Hoveyda's reputation as a meticulously dressed socialite connects him to the Devil's 'sympathizers with beauty'. Golestan emphasised this connection in his production - the Devil dressed in formal attire and had a flower on his lapel, imitating Hoveyda's signature style (11).

While the Shah worked to change the face of Iran to push the country into the twentieth century, paralleling the Devil's narrative in which he claims to call the people of the world from misery and poverty to joy and beauty, Iranian artists continued to grapple with strict state censorship. Hoveyda was at the centre of a particularly controversial episode in which the satirical journal Tofiq (Success) was banned. A widely spread and accepted rumour claimed that this was carried out on Hoveyda's orders, although Milani has since disputed these allegations. ${ }^{91}$ Golestan 
who was no stranger to censorship — his Mysteries of the Treasures at Ghost Valley was quickly banned after release with some also connecting this to Hoveyda reflects on censorship in his translation of Don Juan. Golestan adds this exchange to Shaw's text:

DON JUAN

[At this point, he notices that the Devil has ripped pages out of his book. He takes the shreds from between the pages and throws them at the Devil whilst saying] Can you see what you have done to my book?

DEVIL [Without looking at Don Juan, with composure and conviction] it included discussions that should not be heard. We cut them. Yes (85-6).

This appears just before Don Juan's departure, signalling this as the pivotal moment in which Don Juan arrives at the conclusion that he must leave for Heaven. Golestan would make a similar decision only a few years later; he permanently left Iran in 1975.

Golestan recently returned to his translation of Don Juan. The third Festival of Iranian Theater held in London in 2015 included a rehearsed reading of this translation directed by novelist, playwright, screenwriter and director, Ghazi Rabihavi and attended by Golestan. In response to an interview question in which Rabihavi was asked about his interest in this text, Rabihavi explained that he first encountered Golestan's translation in his youth. Although he enjoyed the play then, he states that he did not fully appreciate the significance of its discussions until he read the work 
again recently: 'This play includes a message that should be heard especially in the situation that we Iranians are in currently — those ideologies, superstitions, and modes of thought that Iranians are grappling with today'. ${ }^{92}$ Rabihavi makes a valid point; there is much in Don Juan that connects with Iran's current political landscape. The Devil's obsession with appearance over reality reminds one of the façade of religious piety that is maintained by Iranian citizens and politicians in public but discarded in private. Moreover, Iran's Islamic revolution confirms Don Juan's assertion that men will take up arms for ideas: 'I am giving you examples of the fact that this creature Man, who in his selfish affairs is a coward to the backbone, will fight for an idea like a hero. He may be abject as a citizen; but he is dangerous as a fanatic' (147). It is questionable, however, whether Don Juan can emerge victorious in this debate if performed again for an Iranian audience. The Devil's cynicism may seem more appealing to some Iranians than Don Juan's revolutionary fervour. The Devil's following assertion is perhaps an apt reflection on Iran's turbulent modern history: 'An epoch is but a swing of the pendulum [...] when you are as old as I am; when you have a thousand times wearied of heaven $[\ldots]$ and a thousand times wearied of hell $[\ldots]$ you will no longer imagine that every swing from heaven to hell is an emancipation, every swing from hell to heaven an evolution' (168).

Shaw's image on the wall in Farhad's study is a fitting symbol for the ways in which Shaw has and continues to inspire Iranian readers and audiences in their pursuits for social and political reforms. For over a century, Iranians have actively sought to alter Iran's political and social institutions as they have vehemently debated issues of individual liberties, social justice, gender equality and national identity. These debates have at times resulted in political upheaval in Iran; the country's modern history is marked with coups, abdications, and revolutions. While the Islamic 
Revolution at first may have seemed as the culmination of these debates that began earlier in the century, it has in many ways intensified and polarized these discussions. It is the continuity in such debates that has led some Iranians to read Shahrzad as an allegory of Iran's current political landscape rather than a dramatization of life in the 1950s. The participation of many Iranians in these debates has been informed by modes of thinking outside Iran, prompted by the translation of European literature and philosophy by the Western-educated elite in the early decades of the twentieth century. Shaw was and remains an obvious choice for many due to the playwright's direct engagement with political and social issues in his drama. A study of Shaw's presence in such debates reveals the ways in which Shaw has spoken to a wide range of concerns and approaches in Iran. This is testament to the endless possibilities in Shaw's theater for fresh perspectives and interpretations. In Drama from Ibsen to Brecht, Raymond Williams argued that Shaw was a victim of his epoch; a playwright who struggles to extend beyond his time and place in history. ${ }^{93}$ It seems that many Iranians would disagree.

\section{NOTES}

${ }^{1}$ John Albert White, Transition to Global Rivalry: Alliance Diplomacy and the

Quadruple Entente 1905-1907 (Cambridge: Cambridge University Press, 1995), 294.

${ }^{2}$ Common Sense about the War, Current History of the European War 1.1 (New York: The New York Times Company, 1914), 11-60, 43.

${ }^{3}$ Shaw had an ambivalent and complicated relationship with the Empire and colonial expansion. He did not oppose imperialism but viewed it as an 
evolutionary stage towards an international federation. To that end, he advocated for an enlightened management of the empire and criticized 'British imperial leadership' and 'the corrupting role played by capitalists such as Cecil Rhodes', see Michael Malouf, 'Empire and Nationalism', George Bernard Shaw in Context, ed. Brad Kent (Cambridge: Cambridge University Press, 2015), 207-214, 210.

${ }^{4}$ F. Kazemzadeh, 'Anglo-Russian Convention of 1907', Encyclopaedia Iranica II.1 (1985), 68-70 < http://www.iranicaonline.org/articles/anglo-russianconvention-of-1907-an-agreement-relating-to-persia-afghanistan-and-tibet> [accessed April 2020].

${ }^{5}$ Common Sense About the War, 45.

${ }^{6}$ Nasserddin Parvin, 'Ettela'at', Encyclopaedia Iranica IX.1 (December 1998), 58$62<$ http://www.iranicaonline.org/articles/ettelaat $>$ [accessed April 2020].

${ }^{7}$ Ettela'at, 2 November 1950, 1.

8 Parvin, 'Ettela'at'.

${ }_{9}^{9}$ Be Suy-e Ayande, Number 152, 3 November, 2.

10 Iran Modern History (New Haven: Yale University Press, 2017), 502.

11 Ervand Abrahamian, Iran Between Two Revolutions (Princeton: Princeton University Press, 1983), 342.

12 Abrahamian, 343.

13 In addition to a review of Everyone's Political What's What, these include a translation titled 'I am an Authoritarian Democrat' (1945) - details of the original are not included - and a review of a translation of Widowers' Houses published in 1955. 
${ }^{14}$ Sukhan, 2.2 (January 1945), 143.

15 Gozidey-e Asnad-e Namayaesh dar Iran (A Selection of Iranian Theatrical Documents), ed. Ali Mir Ansari and Seyyed Mehrdad Ziayi, Vol. 2 (Tehran: Sazman-e Asnad-e Meli Iran Publications, 2002), 20. Hassan Javadi identifies three types of plays during Reza Shah's reign: historicals, romantic musicals and didactical comedies. Plays of this period include Hedayat's Parvin Dokhtar-e Sasan (Parvin, daughter of Sasan), a nationalistic piece concerned with the Arab invasion of Iran, Abbaseh Khahar-e Amir (Abbaseh, Amir's Sister), a romantic musical by Reza Kamal and Dhabih Behruz's Jijak Ali Shah, a play criticizing 'social conditions' in the Qajar period. Little information is available on how these plays were performed but evidence suggests that they included some female performers and incorporated dancing, singing, music and acting. The relatively high number of tickets sold and the existence of amateur dramatic groups indicate that in addition to elite audiences, theatre was also available to a more general spectatorship (see Willem M. Floor, The History of Theater in Iran (Washington D.C.: Mage Publishers, 2005), 260-2.).

16 Fakhruddin Mir Ramezani, 'Mostantegh' (Inspector), Mardom (People), 1947, 15, quoted in Mostafa Oskooyi, Seyri Dar Tarikh-e Iran (A Survey of Theater in Iran) (Tehran: Anahita Publications, 1999), 440.

17 The reviewer of Political What's What in Sukhan claims that few Farsi translations of Shaw's work existed. It is likely then that Alavi read Shaw either in English or German; Alavi travelled to Germany to continue with his education, graduating from the University of Munich in 1928. 
${ }^{18}$ Khaterat e Bozorg Alavi (The Memories of Bozorg Alavi), ed. Hamid Ahmadi (Tehran: Donyay e Ketab, 1998), 101-2.

${ }^{19}$ In addition to Arms and the Man, Jahan-e No also published a review of a production of Shaw's Pygmalion (1948) in this period. This performance was staged in English by the British Council which had appointed its first representative to Iran in 1946 (for an account of the activities of the British Council in Iran see Elr, 'British Council', Encyclopaedia Iranica IV.5, 2010, 455-6 < http://www.iranicaonline.org/articles/british-council-activities-in-iran-1942-79 > [accessed July 2020].

${ }^{20}$ C. Edmund Bosworth, 'Laurence Paul Elwell-Sutton', Encylopaedia Iranica VIII.4 (1998), 372-3 < http://www.iranicaonline.org/articles/elwell-sutton> [accessed April 2020].

21 Jahan-e No, 1.2 (July 1946), 36

22 'A Satirical Play by Bernard Shaw', Jahan-e No, 2.2 (1947), 51.

23 Stephen C. Poulson, Social Movements in Twentieth-Century Iran: Culture, Ideology, and Mobilizing Frameworks (Lanham: Rowman \& Littlefield Publishers, 2006), 148.

24 Plays Pleasant, ed. Dan H. Laurence (London: Penguin Books, 2003), p. 20. All further references are to this edition and are given parenthetically in the text. 25 Jahan-e No, 3.7 (July), 149-50. No reference is provided in the publication for the quote from Shaw.

${ }^{26}$ Amanat, 389.

${ }^{27}$ Karim Soleimani, 'Press Censorship in the Reza Shah Era: 1925-41', Culture and Cultural Politics Under Reza Shah, ed. Bianca Devos and Christop Werner (New York: Routledge, 2014), 181-98, 181. 
28 Talin Grigor, 'The King's White Walls: Modernism and Bourgeois Architecture', Culture and Cultural Politics, 95-118, 107.

${ }^{29}$ Floor, 235.

30 'The Bulgarians of Bernard Shaw's Arms and the Man', SHAW: The Journal to Bernard Shaw Studies 31.1 (University Park: Penn University Press, 2011), 71-88, 72.

${ }^{31}$ Sarbaz-e Shokolati (Chocolate Soldier), trans. Simin Daneshvar (Tehran: Rozaneh Publications, 2014), 21.

32 Hamid Algar, 'Introduction', Occidentosis: A Plague from the West, trans. R. Campbel (Berkeley: Mizan Press, 1984), 9-21, 15. Here Algar is referring to the following aspects of Al-e Ahmad's study: 'the generally invisible but significant links between orientalist scholarship and imperialist politics, the meaningless claim of orientalism to constitute a specialization in itself, without further definition, and the orientalist's assumption that the Muslim East is at bottom static and passive material for analysis by superior minds'.

33 Occidentosis, 34.

${ }^{34}$ Shirin S. Deylami, 'In the Face of the Machine: Westoxification, Globalization, and the Making of an Alternative Global Modernity', Polity 43.2 (Chicago: The University of Chicago Press, 2011), 242-63, 243.

35 Iranian Intellectuals and the West: The Tormented Triumph of Nativism (New York: Syracuse University Press, 1996), 74.

36 Tchaprazov, 72.

37 Occidentosis, 95.

38 Occidentosis, 96. 
39 Occidentosis, 94.

40 Occidentosis, 95.

41 Occidentosis, 93. Here Al-e Ahmad is drawing on the Marxist term 'lumpen'. Marx and Engels considered the lumpenproletariat as a part of the working classes that lacked consciousness and could be used by capitalists as a 'tool of reactionary intrigue' (Karl Marx Frederick Engels Collected Works (New York: International Publishers, 1975), 7, 505.). In the context of Al-e Ahmad's postcolonial criticism, this refers to a lack of awareness amongst the ruling classes in Iran who mistakenly align themselves with the interests of western powers.

42 The review in Jahan-e No includes an image of the production. Two images have also been published in Sarbaz-e Shokolati.

${ }^{43}$ For a comprehensive account of Reza Shah's dress reforms see Houchang E. Chehabi, 'Staging the Emperor's New Clothes: Dress Codes and Nation-Building under Reza Shah', Iranian Studies 26.3/4 (Summer-Autumn 1993), 209-229. 44 Tchaprazov, 76.

45 'A Satirical Play by Bernard Shaw', 51.

46 Amanat, 562.

${ }^{47}$ Arbi Avansian in an interview with Reza Ghasemi and Sadruddin Zahed, Shahin Sarkisian: Bonyangoza-e Taatr-e Novin-e Iran (Sarkisian: The Founder of Modern Iranian Theater), ed. Mina Rahmati, Jamshid Layegh and Gholamhossein Dowlatabadi (Tehran: Hadaf-e Salehin, 2006), 100-117, 100.

48 'Hadaf-e Ma' ('Our Aims'), Sarkisian: Bonyangozar-e Taatr-e Novin-e Iran, 1968. 
${ }^{49}$ Avansian, 110.

50 This is mentioned in a number of biographies and criticisms on Farrokhzad's work including: Ayehaye Ah (Signs of Woe), ed Naser Saffarian (Tehran: Nashr e No, 2016), 317. Sholeh Wolpé also mentions this in her introduction to a translation of Farrokhzad's poetry claiming that 'the story means a great deal to her' (Sin: Selected Poems of Forough Farrokhzad, ed. and trans. Sholeh Wolpé (Fayetteville: The University of Arkansas Press, 2007), xxx.)

${ }^{51}$ A Lonely Woman: Forough Farrokhzad and Her Poetry (London: Lynne Reinner Publishers, 1987), 149.

52 Hillman, 71.

53 Saint Joan: A Chronicle Play in Six Scenes and an Epilogue, ed. Dan H. Laurence (London: Penguin Books, 2003), 40. All further references are to this edition and are given parenthetically in the text.

54 Mahnaz Afkhami, 'The Women's Organization of Iran: Evolutionary Politics and Revolutionary Change', Women in Iran from 1800 to the Islamic Republic, ed. Lois Beck and Guity Neshat (Chicago: University of Illinois Press, 2004), 107-135, 107.

55 Arzoo Osanloo, The Politics of Women's Rights in Iran (Princeton: Princeton University Press, 2009), 27.

${ }^{56}$ Amanat, 563.

57 The term 'slut' did not necessarily have sexual connotations in nineteenthcentury usage. In Shaw's play, however, Joan's promiscuity is suggested in other ways to indicate that Farrokhzad could have read the term to mean this rather than physical untidiness. For instance, Ladvenu, reading the form of recantation, 
refers to Joan's clothes as 'immodest' (141). Moreover, earlier The Inquisitor argues that the culmination of Joan's 'quarrel' with her dress is 'bands of wild women and men who refuse to wear any clothes at all [...] maids will neither marry nor take regular vows, and men reject marriage and exalt their lusts into divine inspirations' (128).

$58 \operatorname{Sin}, 3$.

${ }^{59}$ Hillman, 12.

60 Hillman, 24.

${ }^{61}$ Hillman, 12.

${ }^{62}$ Mansoureh Ettehadieh, 'The Origins and Development of the Women's Movement in Iran: 1906-41', Women in Iran from 1800 to the Islamic Republic, 85-106, 98.

${ }^{63}$ Hillman, 12.

${ }^{64}$ Marina Warner, Joan of Arc: The Image of Female Heroism (Oxford: Oxford University Press, 2013), 29.

${ }^{65}$ Quote from Iranj Gogin interview with Forough Farrokhzad, quoted in Wolpé, xxviii.

${ }^{66}$ Farzaneh Milani, Veils and Words: The Emerging Voices of Iranian Women Writers (New York: Syracuse University Press, 1992), 95.

67 Milani, 58-9.

68 Milani, 61.

${ }^{69} \operatorname{Sin}, 109$. 
70 'From Hens' Eggs to Cinders: Avian Imagery in Shaw's “Saint Joan”,', Rocky Mountain Review of Language and Literature 40.4 (Laramie: Rocky Mountain Modern Language Association, 1986), 213-220, 215.

$71 \operatorname{Sin}, 9$.

$72 \operatorname{Sin}, 67-8$

${ }^{73}$ Forough Farrokhzad: Jadouy-e Javedanegi (Forough Farrokhzad: The Magic of Immortality - Forough's Letters, Interviews, Articles, Stories and Memories), ed.

Behrouz Jalan Pendari (Tehran: Morvarid Publications, 2015), 123.

74 ‘Baraye Digaran Neveshtan’ ('Writing for Others'), Ferdowsi, no. 932 (1986), 26. Quoted in Hillman, 155.

$75 \operatorname{Sin}, 85$. Farrokhzad begins the poem, 'Let Us Believe in the Dawn of the Cold Season' with: 'And here I am/ a lonely woman'.

${ }^{76}$ Fatemeh Keshavarz, Jasmine and Stars: Reading More Than Lolita in Tehran (Chapel Hill: The University of North Carolina Press, 2007), 36.

77 Keshavarz, 36.

78 Golestan describes these events in an interview with Radio Zamaneh in 2015 <https://soundcloud.com/radiozamaneh/auzic4a285er>.

${ }^{79}$ Don Juan dar Jahanam (Don Juan in Hell), trans. Ebrahim Golestan (Tehran: Agah Publications, 1974), 11. All further references are to this edition and are given parenthetically in the text.

${ }^{80}$ Abbas Milani, The Persian Sphinx: Amir Abbas Hoveyda and the Riddle of the Iranian Revolution (Washington, D.C.: Mage Publishers), 257. 
${ }^{81}$ Abbas Milani, 'Hoveyda, Amir-Abbas', Encyclopaedia Iranica XII.5 (2004), 543-

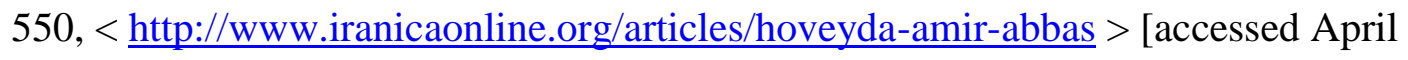
2020].

82 Andrew Scott Cooper, The Fall of Heaven: The Pahlavis and the Final Days of Imperial Iran (New York: Henry Holt and Company, 2016), 201.

83 Milani, 'Hoveyda, Amir-Abbas'.

${ }^{84}$ Milani, The Persian Sphinx, 260.

85 The Playwrighting Self of Bernard Shaw (Carbondale: Southern Illinois University Press, 1991), 46.

${ }^{86}$ Man and Superman: A Comedy and a Philosophy, ed. Dan H. Laurence (London: Penguin Books, 2004), 149. All further references are to this edition and are given parenthetically in the text.

${ }^{87}$ Milani, The Persian Sphinx, 233.

88 Cooper, 200.

89 Milani, The Persian Sphinx, 259.

${ }^{90}$ Amanat, 618.

91 Milani, 255-6

${ }^{92}$ Rabihavi also features in the report produced by Radio Zamaneh <https://soundcloud.com/radiozamaneh/auzic4a285er>. ${ }^{93}$ Drama from Ibsen to Brecht (London: Hogarth Press, 1968), 258. 